\title{
The Role of Proportionality in International Investment Law and Arbitration: A System-Specific Perspective
}

\author{
Eric De Brabandere \\ Professor of International Dispute Settlement and Director, Grotius Centre \\ for International Legal Studies, Leiden University, Leiden, The Netherlands; \\ Attorney-at-Law, Brussels Bar \\ e.c.p.d.c.de.brabandere@law.leidenuniv.nl \\ Paula Baldini Miranda da Cruz \\ Doctoral candidate, Grotius Centre for International Legal Studies, Leiden \\ University, Leiden, The Netherlands; Managing Editor, Leiden Journal of \\ International Law; Attorney-at-Law, Brazilian Bar \\ p.baldini.miranda.da.cruz@law.leidenuniv.nl
}

\begin{abstract}
In this article, we examine the place of proportionality and related tests in international investment law and arbitration by looking specifically at the challenges faced by this field on applying proportionality coherently and consistently. We also assess where proportionality has been used in international investment law and arbitration. We argue that a sound appreciation of proportionality in international investment law requires taking into account the inherently imbalanced conception of international investment agreements, the incoherence of the international investment law regime, and the ad hoc dispute settlement method tasked with applying and interpreting a variety of imprecise and diverging norms. Therefore, international investment law and arbitration have not developed an institutionalised approach towards proportionality. Since investment agreements and international investment arbitration form a rather incoherent collective of cases and, as a result, have not developed a single or uniform approach towards proportionality, there is a tendency to individually approach cases.
\end{abstract}




\section{Keywords}

investment arbitration - proportionality - balancing tests - investment law

\section{Introduction}

Proportionality is a general principle of international law that presupposes that an examination of a possible conflict between different rights will follow some general rational rules that have the goal of ensuring that even restricted rights will not be completely suppressed. ${ }^{1}$ It is, therefore, a principle that guides decision-makers towards adopting more analytical rationales when dealing with tensions between rights and interests. ${ }^{2}$ Although proportionality is, today, often taken for granted as a natural part of most legal systems, its formulation is too general and open-ended to be directly applied to cases. ${ }^{3}$ In other words, although the proportionality principle requires decision-makers to examine tensions between rights and/or interests rationally, and in the end decide which interests prevail, it does not establish what kind of rationale they should follow. It is, therefore, up to decision-makers, such as judges and legislators, to determine how to implement proportionality in practice.

In international investment law and arbitration, the discussion on the role of proportionality can be tackled from different perspectives. One can look at the question where, and how, international investment agreements, and perhaps international investment law more generally, can be considered proportional and which rights and/or interests need to be in proportion to what. Another angle is to question by which standard one can appraise precisely the question whether various rights and interests are in proportion, ${ }^{4}$ or how proportionality is used or can be a useful method in

1 For a genealogy on minimum core obligations, see J. Tasioulas, 'Minimum Core Obligations: Human Rights in the Here and Now', World Bank Research Paper (2017), <openknowledge. worldbank.org/handle/10986/29144>. All websites were accessed on 11 November 2019, unless otherwise mentioned.

2 A.S. Sweet, and J. Mathews, 'Proportionality Balancing and Global Constitutionalism' 47:72 Columbia Journal of Transnational Law (2008) pp. 74-75.

3 Ibid., p. 76.

4 On the question of standard-setting and 'balancing' of investment agreements generally, see, generally: E. De Brabandere, '(Re)Calibration, Standard-Setting and the Shaping of Investment Law and Arbitration', 59:8 Boston College Law Review (2018) pp-26o7-2634 (explaining that investment agreements are mostly composed of protection clauses). 
applying the various standards of investment protection usually contained in investment treaties. ${ }^{5}$

By looking at international investment agreements alone, we usually see agreements mainly composed of protections standards for the benefit of foreign investors and little to no provisions concerning the rights of the host States of foreign investment or obligations of foreign investors. This, as we will argue, is how international investment agreements are construed or at least were originally conceived. Due to the multilateralization of international trade, the specific protection afforded to foreign investors was left unregulated at the international treaty level, paving the way for the contemporary regulation of foreign investment through bilateral investment treaties. International investment agreements are, therefore, naturally imbalanced agreements because they are specifically designed to protect foreign investment in order to encourage investors to invest abroad. From the perspective of the interests that are at stake, one could argue that - seemingly - the balancing of interests is done at the treaty-negotiation stage. The rights granted to foreign investors are then the result of the balancing of interests - they do not again need to be subjected to a balancing exercise by the arbitral tribunal reviewing infringements of those rights.

However, the fact that investment arbitration agreements are seemingly onesided does not mean they are meant to only protect foreign investors in absolute terms, and that there is no room for taking into consideration rights and interests other than those of the investor. In fact, investment tribunals are regularly faced with disputes that require them to balance interests of foreign investors and those of (host) States, notably when certain rights granted to foreign investors themselves contain a certain balancing test. Investment agreements, however, often provide little guidance for tribunals to deal with conflicts between interests of investors and States. ${ }^{6}$ In line with the overall objective of international investment agreements to attract foreign investment by offering protection to investors and the inherently 'imbalanced' nature of these agreements, considerations surrounding issues of proportionality between investors and home States will, therefore, inevitably force arbitrators to develop their own balancing techniques.

In this article, we examine the place of proportionality and related tests in international investment law and arbitration. As a general principle, proportionality does not require decision-makers to follow any specific rationale or analysis for dealing with tensions between different rights and interests. Therefore, for a decision to be considered proportional, it does not need to

5 See, generally: C. Henckels, Proportionality and Deference in Investor-State Arbitration: Balancing Investment Protection and Regulatory Autonomy (CUP, Cambridge, 2015).

6 Ibid., pp. $10 \mathrm{ff}$ and $173 \mathrm{ff}$. 
follow any specific reasoning, as long as it is rational, or analytical, or at least in line with the applicable law. In international law, courts have followed several different paths when applying proportionality into their decision-making. This, we will argue, can be explained by two main factors. First, the specific norms at stake will influence whether and how courts and tribunals can and will engage in proportionality assessments. Secondly, courts that are part of centralised legal systems have often developed rather sophisticated tests to balance rights and interests, and have integrated these tests into a consistent line of jurisprudence. Arbitral tribunals in investment law, on the other hand, have engaged with proportionality in a more casuistic way.

We will therefore start with examining the proportionality methodology applied by human rights courts, an established methodology for such a test in international law. We explain that these tests can only be developed and effectively applied under very specific normative and systemic conditions, as has been the case in international human rights courts (section 2). In contrast, international investment agreements and arbitration form a rather incoherent collective, and as a result, have not been prone to the development of a single or uniform approach towards proportionality (section 3). As a result, arbitrators tend to individually approach cases and use the terminology of proportionality to calibrate investor and State interests (section 4).

Before moving on, a couple of remarks are necessary to explain the comparison made with international human rights courts. Human rights have protection and international investment law share several common features. First, there is a similarity in the relative 'weakness' of the position of individuals and foreign investors in relation to the State, which has resulted in the grant of individual rights in order to 'protect' them against exercises by the State of its sovereign prerogatives. Secondly, the grant of rights of protection to both individuals and investors has also resulted in the creation of specific dispute settlement mechanisms to address alleged violations of these rights by the State. To a certain extent indeed, the direct access of individuals to international investment arbitrations is very analogous to the direct access of individuals to international human rights courts and bodies. The main differences between human rights litigation and investment arbitration are that in international human rights litigation the States which have accepted the direct claims rights of individuals have also principally accepted such a right for claims of their own nationals, ${ }^{7}$

7 P.-M. Dupuy, 'Unification Rather than Fragmentation of International Law? The Case of International Investment Law and Human Rights Law', in P.-M. Dupuy, F. Francioni and E.-U. Petersmann (eds.), Human Rights in International Investment Law and Arbitration (OUP, Oxford, 2009), p. 48. 
and the dispute settlement system in human rights litigation is institutionally centralised compared to investment arbitration.

\section{Proportionality Tests in International Law: The Example of Human Rights Courts}

Proportionality, as a general principle of public international law, requires only that those involved in decision-making make use of rational criteria and work to maximise rights and interests of all those involved in a legal dispute. Its main goal is to restrict the authority of decision-makers and prevent them from resolving tensions between different rights arbitrarily. Proportionality, therefore, imposes on decision-makers the additional burden of making sure that their decisions are duly justified. Different systems and courts have developed various methodologies for applying the general principle of proportionality in practice. The most popular of those methodologies has been, by far, the use of tiered tests where the decision-maker makes use of multiple criteria to see if the restrictions imposed by the State are necessary, adequate and strictly proportional to the goals of the restrictions.

In international law, tiered proportionality tests (commonly referred to as 'balancing tests') became best known in human rights courts, responsible for examining violations of human rights rules by States. In essence, the balancing tests they apply aim to examine interferences with human rights in light of States' discretion to enact their own laws and policies. ${ }^{8}$ The human rights' legal framework (treaties and jurisprudence) often contain guidelines as to how to apply proportionality and balance rights in each situation. Treaties will usually specify whether a human right such as the right to freedom of expression or assembly may be restricted, under what conditions, and to what extent. ${ }^{9}$ These clarifications help steer tribunals' interpretations towards a certain direction, but must still be applied to the specific contexts under which they are brought in. Therefore, the interpretation and application of human rights standards

8 Henckels, supra note 5, p. 15.

9 See, e.g., the example of the right to freedom of expression in Council of Europe, European Convention on Human Rights, ETS 5, Art. 10(2) (authorising restrictions to preserve national security, territorial integrity or public safety, to prevent crimes, to protect health and morals, the integrity of others, or confidentiality in specific cases); Organization of American States, American Convention on Human Rights, Art. 13 (2) (allowing restriction to the right of freedom of expression in the form of subsequent liability to ensure the respect for the rights and reputations of others and the protection of national security, public order, public health or morals). 
can vary significantly from one court to another, even if the rules are drafted in a similar way.

The European Court of Human Rights generally avoids detailed examinations on whether domestic authorities' actions and the policy objectives behind them are effectively proportional. Instead, the analysis is procedural: it focuses on whether domestic authorities made use of a balancing test when adopting a measure restricting human rights. The balancing test applied by the European Court therefore requires domestic authorities to ensure that restrictive measures (i) are the result of a law; (ii) have the goal of protecting general interests; and (iii) are specifically designed to protect those interests. ${ }^{10}$ If a government action complies with these requirements and the guidelines established in the European Convention for each right, the restriction will be considered lawful under the European Convention. This means that, instead of balancing rights themselves, the European Court will usually defer to the exercises carried out domestically. The amount of deference granted by the Court varies with the specific circumstances of the case, but, in general, the European Court grants States much less deference when it comes to rights known as 'core' or 'fundamental' rights, such as freedom of expression and association and prohibition against torture, than it does with property rights. ${ }^{11}$

The Inter-American Commission and Court of Human Rights adopted a similar method but with a different approach from the method employed by the European Court of Human Rights. The test used by the Inter-American Court is composed of the same steps applied by the European one, plus an examination of whether the restrictive measures were necessary and proportional in the narrow sense. ${ }^{12}$ The main consequence of adding these two steps is that the Inter-American system examines not only whether States balanced different interests when they decide to restrict certain human rights but also whether they executed these restrictions within the limits set by the American Convention on Human Rights. Instead of deferring to the States' balancing tests, the Inter-American Court applies its own test to conclude whether State

10 See B. Çali, 'Balancing Test: European Court of Human Rights', in Max Planck Encyclopedia of International Procedural Law (OUP, Oxford, 2018) paras. 16-19, <opil.ouplaw.com/ view/10.1093/law-mpeipro/e3426.013.3426/law-mpeipro-e3426?rskey=JbdTX3\&result=1\&prd $=$ OPIL $>$.

11 See P. Contreras, 'National Discretion and International Deference in the Restriction of Human Rights: A Comparison between the Jurisprudence of the European and the InterAmerican Court of Human Rights', 11:1 Northwestern Journal of International Human Rights (2012) p. 3 o.

12 Atala Riffo and Daughters v. Chile, 24 February 2012, IACtHR, Merits, Reparations and Costs, para. 164 . 
actions comply with the Convention. When conducting such analyses, the Court often ends up interfering with States' actions and decisions. ${ }^{13}$ The test applied by the Inter-American Court reflects its tendency to afford less deference to States than its European counterpart, ${ }^{14}$ a move that has been heavily criticised by some commentators. ${ }^{15}$

Although these tests are, on their face, similar, the way that human rights courts have applied them is different. These different applications reflect how each court perceive its role and institutional goals: the European Court of Human Rights focuses on providing legal and procedural support for States to implement themselves these rights and correct course when necessary. On the other hand, the Inter-American Court assigned itself a role of an active developer of substantive human rights in the region, ${ }^{16}$ which implies more interference with the substantive merits of acts under scrutiny and ordering States to change them if it deemed necessary. Despite the differences between how these bodies have institutionally conducted such examinations, they present internally coherent views on what a proportionality test should be.

Balancing tests are subject to several limitations, particularly regarding their capacity to provide solutions to tensions between different categories of rights. 'Balancing' presupposes that the rights in conflict are being somehow weighted against each other, and such measuring requires that these rights are comparable or can be measured based on a single set of criteria or values, which is not always the case. Balancing tests are therefore only one of the many possible forms of applying the proportionality principle in practice - even human rights courts have applied other proportionality principles in their case law. ${ }^{17}$ Nevertheless, they have become extremely prevalent, and balancing tests have

13 See, e.g., Artavia Murillo and Others ('In Vitro Fertilization') v. Costa Rica, 28 November 2012, IACtHR, Preliminary Objections, Merits and Reparations (ordering the Costa Rica to turn over its legislation on in vitro fertilisation) and Gomes Lund and Others ('Guerrilla of Araguaya') v. Brazil, 14 November 2010, IACtHR, Preliminary Objections, Merits and Reparations (declaring the Brazilian amnesty law invalid).

14 For a comparison on how the European and Inter-American Court on Human Rights defer to States, see, generally: Contreras, supra note 11.

15 See, e.g., E. Malarino, 'Judicial Activism, Punitivism and Supranationalisation: Illiberal and Antidemocratic Tendencies of the Inter-American Court of Human Rights', 12:4 International Criminal Law Review (2012) pp. X-Xx.

16 The Inter-American Court's tendency of developing human rights in the region is particularly clear in the determination that the Court's interpretation and standards issued in a particular case should be opposable to all member States. See Almonacid-Arellano et al. v. Chile, 26 September 2006, IACtHR, Preliminary Objections, Merits and Reparations, para. 124.

17 See, e.g., Jersild v. Denmark, 23 September 1994, App. No. 1589o/89 ECtHR, Judgement (Merits and Just Satisfaction) para. 35 (examination based on the chilling effect of the State's 
been often presumed as the main form of translating the proportionality principle to practice, thus referred to as 'a key interpretative principle' in human rights practice. ${ }^{18}$

The acceptance of balancing tests can perhaps be explained by their capacity to establish a clear list of priorities in decision-making while being flexible enough to be used in various situations and cultures and giving an opportunity for tribunals to develop consistent and predictable approaches to situations of tensions between different rights and interests. However, developing such a test and using it effectively requires a system where rights can be measured and effectively valued against each other, and in which the interests to be protected are clear. It therefore requires rights to involve similar kinds of interests. ${ }^{19}$ Moreover, the term test suggests that a specific methodology that can be applied throughout the jurisprudence of a court. Therefore, such a test can only be developed and applied in a legal system that is sufficiently centralised to approach problems uniformly - otherwise, it becomes difficult to assess whether the test of proportionality is proportional in itself. However, not all legal systems present the necessary conditions for developing and applying balancing tests effectively.

\subsection{Investment Law as a Naturally Imbalanced System}

The popularity of balancing tests has turned them into somewhat a general standard as to how to apply proportionality in practice, making it common for other areas of public international law to use those tests as if they were the obvious go-to solution to conflicts of rights or interests. In investment arbitration, tribunals in cases such as Tecmed have advocated for the use of the balancing test or some derivation of it. ${ }^{20}$ Other cases also imported human rights courts' balancing test or some of its elements to draw conclusions on tensions between rights and interests. ${ }^{21}$ International investment law, in particular, is a

actions). See also B. Çali, 'Balancing Human Rights? Methodological Problems with Weights, Scales and Proportions', 29:1 Human Rights Quarterly (2007) p. 261.

18 Çali, supra note 17, p. 259.

19 Ibid., p. 257.

20 Técnicas Medioambientales Tecmed v. United Mexican States, 29 May 2003, ICSID Case No $\mathrm{ARB}(\mathrm{AF}) / \mathrm{oo} / 2$, Award, para. 139 .

21 See, e.g., International Thunderbird Gaming Corporation v. The United Mexican States, 26 January 2006, Award (Separate Opinion of Mr. Thomas Walde) para. 27; Electrabel S.A. v. Hungary, 25 November 2015, Award, para. 179; Phillip Morris Brands Sàrl (Switzerland), Philip 
naturally imbalanced field, given that investment agreements are mostly composed of investment protection clauses, with little mention to other goals such as promoting investment in the host States.

Consequently, from the viewpoint of the treaty as a whole, the interests at stake are more visible at the level of the treaty negotiations that in the rights granted. A balance of interests between States is struck in the conclusion of the treaty and the formulation of the rights granted to foreign investors. Secondly, from the viewpoint of the rights granted to foreign investors, one sees that they are often not formulated as implying in themselves a balancing of interests. It is generally agreed that bilateral investment agreements are a natural reflection of the relative negotiation power and the interests of the States involved in the negotiation of the agreement and that bigger asymmetries of power will lead to treaties which favour the interests of one of the parties more than others. ${ }^{22}$

However, the natural imbalance of international investment law is also a consequence of how they came to exist: international investment agreements were developed to fulfil a specific role within a larger context of trade multilateralization. Following the Second World War, there was a general perception that one of the causes of the war had been the incapacity of States to recover on their own from the economic impact of the First World War. ${ }^{23}$ Efforts to develop a lasting peace structure therefore included substantive global economic reforms that targeted the economic cooperation and development of States, including the establishment of a multilateral system that would support post-war economic recovery and enhance cooperation among States.

The multilateral trade system did not, however, include the promotion and protection of foreign investment, leaving States to negotiate such treaties separately on a bilateral and/or regional basis. The protection provisions and other clauses of investment agreements were therefore developed to fill the gap in investment protection left by these core trade-oriented instruments. ${ }^{24}$ The number of clauses dealing with investment protections in international investment agreements and the traditional lack of more broader regulatory provisions may therefore be a result of international investment agreements

Morris Products S.A. (Switzerland) and Abal Hermanos S.A. (Uruguay) v. Oriental Republic of Uruguay, ICSID Case No. ARB/10/7, Award, para. 399.

See A. Mills, 'The Balancing (and Unbalancing?) of Interests in International Investment Law and Arbitration', in Z. Douglas, J. Pauwelyn and J. E. Viñuales (eds.), The Foundations of International Investment Law: Bringing Theory into Practice (OUP, Oxford, 2014) p. 444.

23 See D.A. Irwin, P. C. Mavroidis and A. O. Sykes, The Genesis of the GATT (CUP, Cambridge, 2008) pp. 13-14.

24 See S. Puig, 'The Merging of International Trade and Investment Law', 33:1 Berkeley Journal of International Law (2015) pp. 8-11. 
being specifically designed to fill the gap left by the multilateral regulation of international trade.

International investment agreements were developed as a small part of a larger international legal context and must be understood and interpreted in that context. ${ }^{25}$ Because of that, investment agreements are not always about creating situations in which all elements, such as investor protection, investor obligation, or even the host State and the foreign investor, are equal or 'in proportion'. But, significantly, the protection of foreign investment is not the objective of a treaty. Rather, the objective of a treaty is broader as it involves the promotion of foreign investment and capital flows between two or more States and the economic development of States. ${ }^{26}$ The investment protection provisions and the access to arbitration for foreign investors usually provided in international investment agreements are merely a means to achieve this goal. While the general objectives of stimulating capital flows and attracting foreign capital - viewed from the perspective of the host State - may nowadays seem somewhat remote, it is nonetheless in the DNA of international investment agreements. The remoteness between the overarching objective and the practical reality that international investment agreements are mainly used for investment protection is understandable since many international investment agreements bear as title 'Agreement for the Promotion and Protection of Investment'.27 Although implying a double objective -promotion and protection, in practice the vast majority of investment agreements contain mainly investment protection provisions. ${ }^{28}$

From that perspective, when one seeks to analyse how international investment law and arbitration are currently regulated and shaped, the idea of 'balance'

25 Ibid., explaining how international trade regulation developed in contrast to international investment law.

26 See J. W. Salacuse, The Law of Investment Treaties (OUP, Oxford, 2009) p. 191 (explaining the 'promotion' aspect of investment treaties).

27 See, e.g., Agreement for the Promotion and Protection of Investment for the Promotion and Protection of Investment between the Republic of Austria and the Federal Republic of Nigeria, Austria-Nigeria, Aug. 8, 2013, <investmentpolicyhub.unctad.org/Download/TreatyFile/2972>.

28 There are several international investment agreements which not only have 'promotion of investment' as an overarching objective, but also have specific provisions aimed at the promotion. See Agreement on Encouragement and Reciprocal Protection of Investments, Arg.-Neth., 20 October 1992, 2242 U.N.T.S. 205, Art. 2 <investmentpolicyhub.unctad. org/Download/TreatyFile/107>, (providing that "[e]ither Contracting Party shall, within the framework of its laws and regulations, promote economic cooperation through the protection in its territory of investment of investors of the other Contracting Party. Subject to its right to exercise powers conferred by its laws or regulations, each Contracting Party shall admit such investments"). 
as an evaluative device for proportionality is limited, in the sense that arbitral tribunals would have to assign to themselves the mandate to balance the interests of the host State and the rights of foreign investors. International investment agreements were not conceived as regulatory instruments intended to offer a general regulatory environment for foreign investment, in which both the rights and obligations of foreign investors and those of the host States of the investment and home State of the investor are grouped and detailed. Such 'self-mandated' proportionality assessment would therefore be the results of tribunals concluding that specific conditions of a treaty are so imbalanced that they may harm the broader purposes of investment law as a promoter of investment.

While preambles of international investment agreements may "suggest the need for a balanced approach that takes into account the rights of both states and investors", ${ }^{29}$ these agreements do, in fact, little to either concretise the obligations of States, absent any specific provisions to that effect, nor does it or to explain precisely how such balancing would work in practice. ${ }^{30}$ Moreover, tribunals have only a one-sided view of what the signatory States of the treaty could have envisioned, given that only one of the signatories is present in most investment arbitration cases, limiting the capacity of tribunals to have a picture of what were indeed the interests that must be balanced..$^{31}$ As a consequence, proportionality only comes into play in relation to certain specific tests applicable in well-defined areas, as will be discussed below.

There is perhaps, one exception to the overall idea that investment agreements as a whole were not conceived as being in themselves 'proportional' or 'balanced': the recently resurfaced emphasis on States' right to regulate, ${ }^{32}$ which despite contemporary resurgence was in fact never in doubt as a general principle but perhaps somewhat obfuscated by overly literal interpretations of investment protection standards. ${ }^{33}$ The right to regulate can be defined as the right permitting States to regulate "in derogation of international commitments it has undertaken by means of an investment agreement without incurring a duty to compensate". ${ }^{34}$ An explicit provision on the 'right to regulate'

29 Henckels, supra note 5, p. 10.

3 Ibid.

31 Mills, supra note 22, p. 453.

32 See A. Titi, The Right to Regulate in International Investment Law (Nomos Verlag/ Dike Verlag/ Hart, Baden-Baden/Zürich/St. Gallen/Oxford, 2014) p. 376.

33 On this, see E. De Brabandere, 'States' Reassertion of Control over International Investment Law: (Re)Defining "Fair and Equitable Treatment" and "Indirect Expropriation", in A. Kulick (ed.), States' Reassertion of Control over International Investment Agreements and International Investment Treaty Dispute Settlement (CUP, Cambridge, 2016) pp. 285-308. 
was for instance included in the recent Comprehensive Economic and Trade Agreement (CETA) ${ }^{35}$ between the European Union (EU) and Canada:

1. For the purpose of this Chapter, the Parties reaffirm their right to regulate within their territories to achieve legitimate policy objectives, such as the protection of public health, safety, the environment or public morals, social or consumer protection or the promotion and protection of cultural diversity.

2. For greater certainty, the mere fact that a Party regulates, including through a modification to its laws, in a manner which negatively affects an investment or interferes with an investor's expectations, including its expectations of profits, does not amount to a breach of an obligation under this Section. ${ }^{36}$

By recognising that States are allowed to regulate their domestic affair and protect interest such as 'essential security interests', 'public order' and 'the public interest' without breaching investment treaties is a way of restoring the balance to investment law. ${ }^{37}$ The concretisation of States' right to regulate as a principle or as a stand-alone provision in an investment agreement can be viewed as including a general proportionality test for investment protection provisions. Yet, the formulations of the right to regulate, notably the one cited above, do not explicitly include any reference to a proportionality test and seem to be more intended as a reaffirmation of a principle - that States have a right to regulate - to which investment protection provisions provide an exception, but not an automatic one. In addition, the precise effect of such a provision has not been fully tested in practice. Aside from the inclusion of recent programmatic provisions in investment agreements, such as the one cited in the recent CETA, the precise impact of such a clause on the 'equilibrium' of international investment agreements needs yet to be tested. Notably, whether such clauses will at a certain point evolve into the application of a specific test for proportionality, which would involve an assessment of whether restrictions imposed by States on the rights of foreign investors are proportional to the overall aim of the regulation, remains to be seen.

When looking at the substantive rights granted to foreign investors, little room, generally, is given to a balancing or proportionality test in the assessment of infringements of those rights. This is mostly visible when one contrasts investment protection provisions to those usually found in international

35 Consolidated ceta Text (26 September 2014) < trade.ec.europa.eu/doclib/docs/2014/ september/tradoc_152806.pdf>.

36 Ibid., Art. 8.9.

37 Titi, supra note 32 , pp. $72 \mathrm{ff}$. 
investment treaties. The relative similarity in both regimes can be detected from the individual rights granted to either natural (and legal) persons in human rights law and foreign investors in international investment law. The contents of these rights bear some similarity, but are by no means structurally identical, notably because interferences with human rights are typically subjected to a review which consists of assessing, broadly speaking, whether such interference is 'justified'. Acts of the State in breach of human rights norms are formulated as and thus require an assessment of whether the interference is permissible. ${ }^{38}$ Conversely, the rights granted under international investment law have a more stand-alone and binary nature, in the sense that a breach of these rights is not tested against any possible 'justification' (other than the customary law circumstances precluding wrongfulness once an internationally wrongful act has been identified). Acts of the State in breach of the rights granted under investment treaties are assessed by questioning only whether the act in question constitutes a breach of the norm - there is no subsequent test implying an assessment of whether the 'interference' with the enjoinment of the right is justified nor are the norms framed, usually, as a right and the conditions under which 'interferences' or 'restrictions' are permissible or justifiable.

An example is the treatment of acts which constitute expropriation under human rights and investment legal frameworks. ${ }^{39}$ Using the European regional human rights system as example, the regime governing the right to property is based on the right to property as a human right as embodied in Article 1 of Protocol No. 1 to the European Convention on Human rights. The 'right to property' as a human right is the norm, and the European Court of Human Rights assesses whether breaches of that norm or 'interferences' with that right (such as expropriations) are justified, which is tested against several requirements, namely accordance with the law, the public interest and the proportionality of the acts in relation to the legitimate aim pursued. ${ }^{40}$

38 See for instance the requirement that 'restrictions' to the freedom of assembly and association in Article 11 of the European Convention on Human Rights, need to be "prescribed by law and are necessary in a democratic society in the interests of national security or public safety, for the prevention of disorder or crime, for the protection of health or morals or for the protection of the rights and freedoms of others".

39 See E. De Brabandere, 'Complementarity or Conflict? Contrasting the Yukos Case before the European Court of Human Rights and Investment Tribunals (Yukos Universal Limited (Isle of Man) v. The Russian Federation)', 30:2 ICSID Review - Foreign Investment Law Journal (2015) pp. 345-355.

40 See, e.g., ECtHR, OAO Neftyanaya Kompaniya Yukos v. Russia, Application no. 14902/o4, Judgment, 20 September 2011, para. $55^{8}$. 
The norms regulating direct expropriations and the prohibition of indirect expropriation in investment law, on the other hand, are norms in and of themselves - in other words, the prohibition of direct and indirect expropriations in investment law exists as a stand-alone norm in international law, and is not presented in contemporary treaties as an exception to another right such as the right of property. However, the underlying idea of that rule also is, amongst others, the protection of property rights. Clearly, there is a connection between norms regulating direct expropriations and the prohibition of indirect expropriation in investment law and the right to property, but investment law norms are not construed as 'interferences' with the right to property of foreign investors; they are stand-alone obligations of host States towards foreign investors as such. The norm-structure of the prohibition of unlawful expropriation under customary international law and the right of property under international human rights law are thus different. As a consequence, a human rights court will generally determine whether these measures meet the "requirement of lawfulness and, if so, whether they struck a fair balance between the legitimate state interest ... in question and the protection of the ... rights set forth in Article 1 of Protocol No. ${ }^{1 "} .{ }^{41}$ Investment tribunals, on the other hand, use a different standard of review generally, if one could even consider a 'standard of review' to be applicable at all in relation to assessing the legality requirements of expropriations. ${ }^{42}$

\section{2 $\quad$ A Dispersed Regime}

It is risky to pinpoint general rules or principles in international investment law, ${ }^{43}$ and this also is true in the application of proportionality. Other specialised regimes in international law, such as international human rights law, are often built upon universal or regional multilateral agreements that allow actors to distinguish which are the core rules and principles that guide those areas. ${ }^{44}$ In contrast, international investment law has been built upon a constellation

41 ECtHR, OAO Neftyanaya Kompaniya Yukos v. Russia, Application no. 14902/o4, Judgment, 20 September 2011, para. 646.

42 See W. Burke-White and A. von Staden, 'The Need of Public Law Standards of Review in Investor-State Arbitrations', in S. W. Schill (ed.), International Investment Law and Comparative Public Law (OUP, Oxford, 2010) pp. 707-710.

43 See, however, S. Schill, 'General Principles of Law and International Investment Law', in T. Gazzini and E. De Brabandere (eds.), International Investment Law: The Sources of Rights and Obligations (Martinus Nijhoff, Leiden, 2012) pp. 133-181.

44 Such as the GATT in the context of international trade law, or the Geneva Conventions and Hague Regulations in the context of the laws for armed conflict. General Agreement on Tariffs and Trade in Annex I to the 1994 Marrakesh Agreement Establishing the World Trade Organization, 1867 UNTS 187; International Peace Conference. The Hague Conventions of 1899 (II) and 1907 (IV) Respecting the Laws and Customs of War on Land. 
of bilateral and plurilateral investment agreements containing investment protection provisions negotiated on a non-multilateral level. As of January 2019, it is estimated that States have signed almost 2900 international investment agreements, 2400 of which were in force, and around 370 more agreements with investment provisions. ${ }^{45}$ Since international investment agreements have been negotiated individually by two or more States, each agreement contains different protections and standards despite a certain similarity in expression of several standards of protection and other clauses. ${ }^{46}$ Moreover, throughout time, investment agreements evolved. Recent agreements, for example, have much more detailed substantive protection clauses and dispute settlement provisions than earlier ones. ${ }^{47}$ Therefore, although it is possible to identify some common practices and investment protection provisions, international investment agreements are far from homogenous and contain vague and imprecisely formulated standards, making it difficult to generalise or treat international investment agreements as being part of a single and uniform regime. ${ }^{48}$ Compared to other fields, such as international human rights law or the law of the European Union, investment law lacks a general degree of similarity. ${ }^{49}$

Proportionality assessments aim to balance the protections granted by investment agreements to foreign investors and the home States' interests and rights. But on their own investment arbitration agreements usually provide little to no guidance to the interpretation standards of protection afforded to foreign investors and their limits. ${ }^{50}$ Take, for example, the oft-used clause that grants investors the right to 'fair and equitable treatment' (FET). What does it mean to be treated 'fairly' and 'equitably'? The concepts of fairness and

45 United Nations Conference on Trade andDevelopment, 'International Investment Agreements Navigator', <investmentpolicy.unctad.org/international-investment-agreements>.

46 On this, see E. De Brabandere, 'Full Protection and Security and Fair and Equitable Treatment in African Investment Relations: Between Contextual Specificity and Generality', 18:1 Journal of World Investment and Trade (2017) pp. 530-555.

47 Compare, e.g., the number of provisions in dispute settlement in different models of bilateral investment treaties of the United States Office of the U.S. Trade Representative and U.S. Dep't of State, 2012 U.S. Model Bilateral Investment Treaty, Arts. 23-36, <ustr.gov/ sites/default/files/BIT\%2otext\%2ofor\%2oACIEP\%2oMeeting.pdf>, Treaty Concerning the Reciprocal Encouragement and Protection of Investment, Arg.-U.S., Art. VII, 14 Nov. 1991, 31 I.L.M. 124.

48 See, however, the claim that the network of bilateral and regional investment treaties have resulted in a multilateralization of international investment law: S. Schill, The Multilateralization of International Investment Law (CUP, Cambridge, 2010).

49 Henckels, supra note 5, p. 14.

$5^{\circ}$ Ibid., pp. 7-10. 
equitableness are not necessarily legal - lawfulness and fairness are not always the same $\mathrm{e}^{51}$ - and investment treaties usually provide very little clarification ${ }^{52}$ on what parties and tribunals should consider 'fair and equitable', thus leading tribunals to include all sorts of sub-categories within that definition. Moreover, absent an explicit inclusion of a proportionality assessment in treaty provisions containing FET clauses, the application of a proportionality test as a matter of international investment law is not automatic. ${ }^{53}$

The difficulties of interpreting investment protection clauses by tribunals are further complicated by the fact that even similar protections are drafted differently from one treaty to another. Some of them have very open texts, while others provide more specific guidelines for interpretation and establishing standards. ${ }^{54}$ These textual differences between treaties make it nearly impossible for investment arbitration tribunals to refer to each other's case law and establish a continuing jurisprudence on the interpretation of investment protections. Tribunals are only able to develop a uniform approach towards investment protections if the terms under which those protections were drafted are equally uniform. Otherwise, they would be risking overstretching the reach of investment protection provisions and issuing decisions that violate the terms agreed by the parties. Investment tribunals have therefore limited institutional capacity to develop a uniform understanding about provisions on investment protection. Instead, they must focus on examining those provisions, including

$5^{1}$ On justice and fairness, see R. Dworkin, Justice for Hedgehogs (HUP, Cambridge, 2011) pp. 318-320.

$5^{2}$ On definitions and what they exclude, see J. Derrida, Positions (UCP, Chicago, 1975) p. 41.

53 See, e.g., the discussion in Philip Morris v. Uruguay on whether it would be possible to import the concept of 'margin of appreciation' from the European Court of Human Rights to investment arbitration proceedings in Phillip Morris Brands Sàrl (Switzerland) Philip Morris Products S.A. (Switzerland) and Abal Hermanos S.A. (Uruguay) v. Oriental Republic of Uruguay, 8 July 2016, ICSID Case No. ARB/10/7, Award (Concurring and Dissenting Opinion Mr Gary Born) paras. 85-87; and conclusions of tribunals in Siemens A.G. v. The Argentine Republic, 6 February 2007, ICSID Case No ARB/o2/8, Award, para. 354 and Bernhard von Pezold and Others v. Republic Zimbabwe, 28 July 2015, ICSID Case No ARB/10/15, Award, paras. $465^{-466 .}$

54 Compare, e.g., FET clauses in 2009 Agreement between the Swiss Federal Council and the Government of the People's Republic of China on the Promotion and Reciprocal Protection of Investments, Art. 4, (extremely open-textured clause); 2004 Agreement between the Government of the Republic of Croatia and the Government of the Sultanate of Oman on the Promotion and Reciprocal Protection of Investments, Art. 3(2) (international law standard for fair and equitable treatment); and 1992 Treaty between the Government of the United States of America and the Government of Romania concerning the Reciprocal Encouragement and Protection of Investment, Art. II(2) (FET provision refers to arbitrary and discriminatory measures impacting investors' activities). 
proportionality assessments, on an ad hoc basis, that is based on the law and facts applicable to the dispute which they are mandated to settle.

\section{Proportionality Assessments in the Practice of International Investment Law}

The fact that investment tribunals lack the centralisation to develop a uniform test for proportionality assessments does not mean that they neglect or ignore the use of the general principle of proportionality in international investment law. It simply means that each tribunal has to individually examine whether a specific situation requires a proportionality assessment and, if so, how such an assessment shall be made. By looking at the case law, we can see that many tribunals expressed support for the use of proportionality. Such support is usually expressed through general statements in favour of having "a requirement of proportionality", 55 without dwelling into details of how they believe such assessment should be made. The general absence of more careful examinations of different methodologies for assessing proportionality can be explained by the pulverised nature of investment arbitration: as explained above, investment tribunals may rely on proportionality assessments in the case law for guidance but are ultimately forced to tailor the test that fits the (often very specific) provisions in the specific investment agreement they have at hand. As a result, the approaches towards proportionality can vary from very general observations on the importance of such principle for ensuring that the decision will be fair, to detailed examinations that resemble the tiered tests used by human rights courts.

Henckels notes that some tribunals have adopted a similar approach to the one developed by the European Court of Human Rights - that is, focusing on the legitimacy and suitability of the restrictive measures in light of alternatives and restrictions that these measures imply. For example, the tribunals in PL Holdings Sàr ${ }^{56}$ and Occidental No. $2^{57}$ have articulated tests in the same format as adopted by the European Court of Human Rights. In both cases, tribunals eventually concluded that the restrictive measures adopted by States

55 Watkins Holdings Sàrl, Watkins (Ned) BV, Watkins Spain SL, Redpier SL, Northsea Spain Sl, Parque Eólico Marmellar SL, and Parque Eólico La Boga, SL v. The Kingdom of Spain, 21 January 2020, ICSID Case No ARB/14/55, Award, para. 601.

56 PL Holdings S.à.r.l. v. Republic of Poland, 28 June 2017, SCC Case No V2014/163, Partial Award, para. 355 .

57 Occidental Exploration and Production Company v. The Republic of Ecuador, 1 July 2004, LCIA Case No. UN3467, Final Award, para. 416. 
were excessive, either because there were less restrictive alternatives available ${ }^{58}$ or because the State's actions seemed to be politically motivated. ${ }^{59}$ The Continental Casualty tribunal also applied a tiered approach that, in addition to assessing the legitimacy and suitability of the measures, examined whether there were any less-restrictive alternative measures available. ${ }^{60}$

Most investment tribunals that have resorted to proportionality assessments have, however, rejected these tiered tests and focused on more direct examinations of proportionality. Some common criteria chosen by these tribunals for their assessments have been whether: 1) the State could have adopted any less restrictive alternatives to the measures chosen by the respondent; ${ }^{61}$ 2 ) the restrictive measures were backed by factual evidence that they could attain the desired objective; ${ }^{62} 3$ ) the measures implied significant changes in domestic legislation; ${ }^{63}$ or 4 ) if the measures were suitable to the policy objectives behind them. ${ }^{64}$

The proportionality methodologies applied by investment tribunals varied not only in terms of the criteria used but also on how such criteria were applied in practice. For example, the tribunals in the Glamis Gold and SD Myers cases have both decided to examine proportionality by looking at whether there were any less-restrictive alternatives available. However, the way each tribunal conducted such examination was very different: in Glamis Gold, the tribunal looked into whether the host State (United States) considered that there could be other less restrictive measures. ${ }^{65}$ The examination was, therefore, procedural and did not encompass any review of the alternatives considered to see if any of them was effectively less restrictive than the one that the United States ultimately decided to adopt. In contrast, the tribunal in SD Myers compared the Canadian government's actions with alternatives available and concluded that one of the alternatives available was less restrictive than the actions effectively taken by the host State (Canada). Thus, the tribunal concluded that

$5^{8} \quad$ PL Holdings, supra note 56 , para. 375 .

59 Occidental No 2 case, supra note 57, para. 446.

6o Continental Casualty Company v. Argentine Republic, 5 September 2008, ICSID Case No. ARB/o3/9, Award, paras. 208-235.

61 S.D. Myers, Inc. v. Government of Canada, 13 November 200o, Partial Award, para. 221.

62 Valeri Belokon v. Kyrgyz Republic, 24 October 2014, Award, paras. 232, 243.

63 PSEG Global Inc. and Konya Ilgin Elektrik Üretim ve Ticaret Limited Sirketi v. Republic of Turkey, 19 January 2007, Award, paras. 255-256.

64 Total S.A. v. Argentine Republic, 27 December 2010, ICSID Case No ARB/04/1, Decision on Liability, paras. $327-328,333$.

65 Glamis Gold, Ltd. v. The United States of America, 8 June 20o9, Award, para. 181. 
Canada violated its obligations under NAFTA because it had failed to adopt the action "that is most consistent with open trade". 66

Unfortunately, tribunals often provide little detail on the reasons that lead them to choose one criterion for assessing proportionality over another. Instead, most tribunals that choose to apply proportionality tests seem to justify their application based on common-sense, saying that it is necessary to balance certain rights ${ }^{67}$ or that a specific measure must be proportional ${ }^{68}$ or applied reasonably. ${ }^{69}$ It is interesting to note that even tribunals that justify the use of certain criteria on more normative grounds, such as pre-existing case law, ended up turning to a more subjective application of the criteria that arbitrators seemed to be more comfortable with. In Tecmed v. Mexico, the tribunal made explicit reference to the balancing test applied by the European Court of Human Rights, thus suggesting that it would follow the same tiered test as the one used by the Court. However, in the end, the tribunal's considerations were limited to the objectives of the measures enacted by Mexico and their effects over the investment. ${ }^{70}$

It is worth noting here that a proportionality assessment based on one simple criterion is not less legal than a complex test composed by multiple steps or tiers. Since there is no pre-existing rule determining under what circumstances tribunals should assess tensions based on proportionality and the methodology they should apply, tribunals are compelled to examine these issues based on the specific conditions of each treaty they have at hand. Such ad hoc assessment implies that tribunals are generally free to establish whatever methodology they see as fit to deal with the specific case they have at hand, regardless of its complexity. The restrictions to their decision-making are those set by the parties in the investment agreement.

At the same time, having too many different solutions may impact the parties' confidence in the authority of investment arbitration tribunals. ${ }^{71}$ While

66 S.D. Myers case, supra note 61, paras. 221, 255.

67 See, e.g., Watkins Holdings et al. v. Spain, supra note 55, para. 6o1; Novenergia II - Energy \& Environment (SCA) (Grand Duchy of Luxembourg) SICAR v. The Kingdom of Spain, 15 February 2018, Award, para. 657 .

68 Stadtwerke München GmbH, RWE Innogy GmbH, and Others, 2 December 2019, ICSID Case No. ARB $/ 15 / 1$, Award, paras. 256, 323-327.

69 See, e.g., Saluka Investments BV(the Netherlands) v. the Czech Republic, 17 March 2006, Partial Award, para. 255; AES Summit Generation Limited and AES-Tisza Erömü Kft v. Republic of Hungary, 23 September 2010, ICSID Case No. ARB/o7/22, Award, para. 9.3·73; ibid., paras. 300,326 .

70 Tecmed, supra note 20, paras. 139, 145, 147.

71 See S. D. Franck, 'The Legitimacy Crisis in Investment Treaty Arbitration: Privatizing Public International Law Through Inconsistent Decisions', 73:4 Fordham Law Review (2005) (on how inconsistency and investment arbitration's legitimacy); See J. Kurtz, 'Building Legitimacy 
there is no legal requirement for tribunals to rely on existing case law - and, as we have explained, it is often undesirable for them to do so - parties generally expect tribunals to behave consistently. ${ }^{72}$ The reason why they decide to resort to arbitration in the first place is because they believe that such a tribunal would be capable of providing them with a legally sound and reasonable solution qualities that are in law intrinsically associated with consistency. Moreover, it could be argued that the individualised approach of investment tribunals can actually harm the possibility of development of a broader systemic balance of international investment law. ${ }^{73}$ Hence, this is why many of the discussions about investment arbitration revolve around how to improve the consistency and predictability of decisions. ${ }^{74}$ Some arbitrators have themselves advocated for the use of balancing tests (borrowed or adapted from other international tribunals) as "more determined"75 legal test than others. Yet, the situation is the pragmatic consequence of a lack of multilateral agreement on both substance and procedure, and hence inherent in the contemporary conceptualisation of international investment law and arbitration by States.

Proportionality presents very specific challenges to investment arbitration. On the one hand, problems related to proportionality are not limited to any particular branch or kind of law - after all, proportionality deals with coordinating different interests to solve conflicts. On the other hand, international investment agreements, which are the main provisions that arbitrators deal with in

through Interpretation in Investor-State Arbitration: On Consistency, Coherence, and the Identification of Applicable Law' in Z. Douglas, J. Pauwelyn and J. E. Viñuales (eds.), The Foundations of International Investment Law: Bringing Theory Into Practice (OUP, Oxford, 2014).

72 See Saipem SpA v. People's Republic of Bangladesh, 30 June 2009, ICSID Case No. ARB/o5/7, Award, at para. 9o. On the general importance of consistency, see also Kurtz, supra note 71.

73 Mills, supra note 22, p. 454.

74 See, e.g., M. Bungenberg and A. Reinisch, From Bilateral Arbitral Tribunals and Investment Courts to a Multilateral Investment Court: Options Regarding the Institutionalization of Investor-State Dispute Settlement (Springer, Cham, 2018); D.M. Howard, 'Creating Consistency Through a World Investment Court', 41:1 Fordham International Law Journal (2017), K. DielGligor, Towards Consistency in International Investment Jurisprudence: A Preliminary Ruling System for ICSID Arbitration Brill Nijhoff, Leiden, 2017.

75 See, e.g., Franck Charles Arif v. Republic of Moldova, 8 April 2013, Award, para. 537; and Blusun S.A., Jean-Pierre Lecorcier and Michael Stein v. Italian Republic, 27 December 2016, Award, para. 318 . 
their cases, provide little guidance for how to solve these issues. In fact, in their current form, investment agreements are quite unbalanced and there is no general rule that they must be balanced as a requirement of law. Moreover, the diversity in the content and clauses of investment agreements prevent investment tribunals from developing an institutional approach towards proportionality, such as the ones developed by the human rights monitoring bodies. Investment tribunals were and are therefore left with using an ad hoc approach towards interpreting investment protections and standards, which includes deciding when and how to apply proportionality in practice.

Despite general statements favouring proportionality and the use of balancing tests, the majority of investment tribunals refrained from trying to develop general tests or principles related to proportionality. Instead, they develop individual solutions for dealing with conflicts of interests. References to proportionality and proportionality-related terms, such as 'balancing', 'reasonableness' or 'rationality', are often used to support arbitrators' individual views about a case. Whenever investment tribunals attempted to develop a test, in the sense that it is used in human rights courts, these tests have focused on specific rights and situations. These tests differ widely in terms of criteria and on how they are applied. Some of them are borrowed from other international institutions, such as the European Court of Human Rights, but most are independently developed methodologies that make use of one specific criterion or a combination of criteria.

The variations on the balancing tests used by tribunals and their application illustrate how disconnected the international investment law regime is. Notwithstanding their general inclination to at least support proportionality in investment arbitration, tribunals are faced with a myriad of tests, methodologies and case-law referring to proportionality. If tribunals find that there is an existing case-law dealing with similar problems and rights, they may refer to the tests applied in that case-law as a way to preserve resources that would be spent with developing a new test and maintaining coherence, but there is no formal obligation of them to follow case-law. While such diversity reflects the variety in international investment agreements and presents an opportunity for the parties to have decisions specifically tailored to their necessities, it also makes tribunals' decisions less predictable. 